\title{
Effects of Cadmium on Growth, Oxidative Stress and Antioxidant Enzyme Activities in Peanut (Arachis hypogaea L.) Seedlings
}

\author{
Shihua Shan \\ Shandong Peanut Research Institute, Qingdao 266100, China \\ Tel: 86-532-8762-9307Ｅ-mail: shhshan@sina.com
}

Feng Liu

Key Laboratory of Experimental Marine Biology, Institute of Oceanology

Chinese Academy of Sciences, Qingdao 266071, China

Tel: 86-532-8289-8567Ｅ-mail: liufeng@qdio.ac.cn

Chunjuan Li

Shandong Peanut Research Institute, Qingdao 266100, China

Tel: 86-532-8762-9308 E-mail: peanutlab@163.com

Shubo Wan (Corresponding author)

Shandong Academy of Agricultural Sciences, Ji'nan 250100, China

Tel: 86-531-8317-8127Ｅ-mail: shhshan@gmail.com

The first and second authors contributed equally to this work.

Received: February 3, 2012 Accepted: February 20, 2012 Online Published: April 20, 2012

doi:10.5539/jas.v4n6p142 URL: http://dx.doi.org/10.5539/jas.v4n6p142

Financial support came from the following research projects, (1) Modern Agro-industry Technology Research System (CARS-14); (2) Agro-industry Technology Research System of Shandong Province; (3)Bio-resource Innovation and Research Project of Shandong Province.

\begin{abstract}
The effects of different cadmium (Cd) concentrations on growth, oxidative stress, and antioxidant enzymes activities in peanut seedlings of five cultivars were investigated in Hoagland's nutrient solution. The results indicated that the growth of seedlings and the maximal photochemical efficiency of Photosystem II were significantly reduced after treatment with $500 \mu \mathrm{M} \mathrm{Cd}^{2+}$ for 4 days, but no significant difference was detected when exposed to 10 and $100 \mu \mathrm{M} \mathrm{Cd}^{2+}$, with the exception of $\mathrm{FH} 3$ being more sensitive to $100 \mu \mathrm{M} \mathrm{Cd}^{2+}$. The changes in $\mathrm{H}_{2} \mathrm{O}_{2}$ and malondialdehyde contents indicated that $\mathrm{Cd}^{2+}$ stress caused an accumulation of reactive oxygen species and induced oxidative stress when exposed to 100 and $500 \mu \mathrm{M} \mathrm{Cd}^{2+}$. The changes in total soluble protein (TSP) content and antioxidant enzyme activities were similar among the five cultivars. However, in the different concentrations of $\mathrm{Cd}^{2+}$, TSP content and antioxidant enzyme activities showed different trends when compared with control groups. Exposure to $100 \mu \mathrm{M} \mathrm{Cd}{ }^{2+}$ markedly enhanced activities of four antioxidant enzymes in both shoots and roots of all investigated cultivars. Additionally, cadmium stress had a more severe impact on roots as opposed to shoots of seedlings.
\end{abstract}

Keywords: Arachis hypogaea L., Peanut, Cadmium, Reactive oxygen species, Oxidative stress 


\section{Introduction}

Cadmium $(\mathrm{Cd})$ is an extremely significant pollutant because it its highly toxic (Sanità di Toppi and Gabbrielli 1999; Benavides et al. 2005). Its high solubility in water leads to Cd accumulation in soil and plants, and further accumulation in biological systems, which poses a major health concern for humans and animals (Järup 2002). $\mathrm{Cd}$ is not an essential element for plant growth, but it is readily absorbed by the roots and translocated to the upper parts of the plants (Clemens 2001; Chen et al. 2003). Although it has been shown that $\mathrm{Cd}^{2+}$ may have a positive effect on plant growth at low concentrations in some plants (Liu et al. 2008; Sobkowiak and Deckert 2006; Arduini et al. 2004; Aina et al. 2007), it is widely recognized as a toxic element due to its negative effects on plant growth and development. The most visible symptoms of cadmium toxicity in plants are chlorosis, stunting, browning of root tips and leaf rolls (Schützendübel et al. 2002; Chen et al. 2003; Guo et al. 2004). In general, high $\mathrm{Cd}^{2+}$ doses exert a serious influence on the physiological, biochemical and macromolecular properties in plants, including the inhibition of photosynthesis, a reduction in the uptake of essential mineral nutrients, an inhibition of the biosynthesis of chlorophyll, alteration of the water balance, a reduction in the activity of various enzymes and chromosomal aberrations (Clemens et al. 2002; Uraguchi et al. 2006; Ding et al. 2007; Sanità di Toppi et al. 2008).

There has been increasing evidence that suggests that the plant's response to $\mathrm{Cd}^{2+}$ stress has been associated with the generation of reactive oxygen species (ROS). The ROS generally stay at an acceptable level and do not cause oxidative stress due to the antioxidant defense system. However, $\mathrm{Cd}^{2+}$ stress can disturb the balance between the generation and removal of ROS, and cause ROS accumulation in plants which results in oxidative damage, such as lipid peroxidation (Lagriffoul et al. 1998; León et al. 2002; Lin et al. 2007; Razinger et al. 2008). To counteract the toxicity of ROS, plants have developed a defense system that functions to scavenge the cellular ROS. This system consists of enzymes including superoxide dismutase (SOD, EC 1.15.1.1), catalase (CAT, EC 1.11.1.6), peroxidase (POD, EC 1.11.1.7) and glutathione reductase (GR, EC 1.6.4.2), and low molecular weight antioxidants such as glutathione (GSH), carotenoids, phenolics and so on (Apel and Hirt et al. 2004; Benavides et al. 2005).

In the whole plant development, the germination of seeds and the early development of seedlings are the most sensitive stages to changes in their surrounding environment (Chen et al. 2003). In this study, we focused on the early development of peanut seedlings and evaluated their tolerance to different concentrations of $\mathrm{Cd}^{2+}$ in hydroponics culture. The different physiological parameters, including growth of roots and shoots, photosystem II (PS II) activity, levels of oxidative stress and the antioxidant enzyme activities, were investigated in this work.

\section{Materials and Methods}

\subsection{Plant Cultivation}

Peanut (Arachis hypogaea L.) seeds of five cultivars including Huayu19 (HY19), Huayu22 (HY22), Huayu23 (HY23), Fenghua3 (FH3) and Luhua11 (LH11) were obtained from the Shandong Peanut Research Institute in Qingdao, China. Healthy and full seeds selected were surface sterilized with a $0.1 \%(\mathrm{v} / \mathrm{v})$ sodium hypochlorite solution for $10 \mathrm{~min}$ and rinsed three times with distilled water. Seed capsules were peeled off with a sterile forceps. Six seeds from each cultivar were taken as a group, growing in sterile glass dishes with $50 \mathrm{~mL}$ Hoagland's nutrient solution containing $0,10,100$, and $500 \mu \mathrm{M} \mathrm{CdCl}_{2}$. Each seed was cultured for 4 days at $20{ }^{\circ} \mathrm{C}$ with $200 \mu \mathrm{mol}$ photons $\mathrm{m}^{-2} \mathrm{~s}^{-1}$ and using a 14:10-h light:dark photoperiod in a greenhouse. During the culture period, the shoot height and the root length were measured.

\subsection{Determination of Photosystem II (PS II) Activity}

The maximal photochemical efficiency of PS II (Fv/Fm) was determined using a chlorophyll fluorometer (PAM, Walz, Germany). Before the measurements, the peanut leaves were dark adapted by incubation at $20^{\circ} \mathrm{C}$ for 20 min. Six seedlings from each treatment were measured. The maximal photochemical efficiency was calculated according to the following equation: $\mathrm{Fv} / \mathrm{Fm}=(\mathrm{Fm}-\mathrm{Fo}$ )/Fm (Adams and Demmig-Adams 2004). Fo was the minimum fluorescence, $\mathrm{Fm}$ the minimum fluorescence, and $\mathrm{Fv}$ the maximum fluorescence after dark adaptation and the difference between Fm and Fo.

\subsection{Determination of ROS Production}

To quantitatively examine the effects of the oxidative stress caused by $\mathrm{CdCl}_{2}$ exposure, the release of ROS into the nutrient solution was determined by measuring the oxidation of 2',7'-dichlorohydrofluorescein (DCFH) to 2',7'-dichlorofluorescein (DCF) in the presence of peroxidase (EC 1.11.1.7) (Gomes et al. 2005) on a fluorometer (Bio-Rad, USA). One milliter of media surrounding the seeds from each treatment was collected after 96 hours and added to a cuvette containing 2',7'-dichlorofluorescein-diacetate (DCFH-DA, Invitrogen, 50 
$\mu \mathrm{M}$ ), peroxidase (Sigma-Aldrich, $40 \mathrm{U} \mathrm{mL}^{-1}$ ) and esterase (EC 3.1.1.1, Sigma, $0.45 \mathrm{U} \mathrm{mL}^{-1}$ ). The cuvettes were slowly stirred for the continuous reactions, and the measurements were collected in five independent runs.

\subsection{Malondialdehyde (MDA) Assay}

The level of lipid peroxidation was measured by quantifying the content of MDA using thiobarbituric acid (TBA). Samples of shoots or roots $(0.5 \mathrm{~g}$ fresh weight) were homogenized in $5 \mathrm{~mL}$ of $10 \%$ trichloroacetic acid (TCA). The homogenates were centrifuged at $12000 \mathrm{~g}$ for $10 \mathrm{~min}$. After adding $2 \mathrm{~mL}$ of $0.6 \%$ TBA to each $2 \mathrm{~mL}$ aliquot of the supernatant, the mixtures were heated at $95{ }^{\circ} \mathrm{C}$ for $40 \mathrm{~min}$ and quickly cooled in an ice bath. Then the mixture was centrifuged at $4000 \mathrm{~g}$ for $10 \mathrm{~min}$, and the absorbance of the supernatant was recorded at $532 \mathrm{~nm}$ and $450 \mathrm{~nm}$ using the TU-1810 spectrophotometer (Pgeneral, China), respectively (Buege and Aust 1978).

\subsection{Assays for Antioxidative Enzymes Activity}

Samples of shoots or roots $(0.1 \mathrm{~g}$ fresh weight $)$ were homogenized in liquid nitrogen and immediately extracted with $1 \mathrm{~mL}$ of $0.05 \mathrm{M}$ potassium phosphate buffer (pH 7.0) containing $0.25 \%(\mathrm{v} / \mathrm{v})$ Triton X-100 and 1\% (w/v) polyvinylpolypyrrolidone (PVPP) after being cultured for 4 days under $\mathrm{CdCl}_{2}$ treatment. The extracts were centrifuged for $10 \mathrm{~min}$ at $12000 \mathrm{~g}$ at $4{ }^{\circ} \mathrm{C}$. The supernatant was used for measurement of the total soluble protein (TSP) content, SOD, CAT, POD and GR. The TSP content was obtained with Bradford's method (Bradford 1976), and the standard curve of protein concentration was described by use of standard protein solution (Jiancheng Nanjing, China). The absorbance of the solution was measured at $595 \mathrm{~nm}$ using TU-1810 spectrophotometer (Pgeneral, China). SOD activity was determined according to the methods described by Mishra et al. (1993). Reaction mixtures included $14.5 \mathrm{mM}$ methionine, $3 \mu \mathrm{M}$ EDTA-Na $2,2.25 \mathrm{mM}$ nitroblue tetrazolium chloride (NBT), and $60 \mu \mathrm{M}$ riboflavin (27:1:1:1). After adding $50 \mu \mathrm{L}$ of enzyme extract to the $3 \mathrm{~mL}$ reaction mixture in tubes, the reaction was started by placing the tubes under two $15-\mathrm{W}$ fluorescent lamps for 10 min and finished by placing the tubes in the dark for $10 \mathrm{~min}$. The absorbance was recorded at $560 \mathrm{~nm}$. One unit of SOD activity was defined as the quantity of SOD required to produce a $50 \%$ reduction of NBT in $1 \mathrm{~mL}$ of reaction mixture. CAT activity was measured according to the methods described by Beutler (1975). One unit of CAT activity was defined as the quantity of CAT required to decompose $1 \mu \mathrm{mol} \mathrm{H}_{2} \mathrm{O}_{2}$ per minute. POD activity was detected according to the modified method of Xu et al. (2008). One unit of POD activity was defined as the change in absorbance at $470 \mathrm{~nm}$ per minute. GR activity was determined according to the modified method of Ekmekci and Terzioglu (2005). The assay mixture contained $200 \mathrm{mM}$ potassium phosphate buffer (pH 7.0), 0.2 $\mathrm{mM}$ EDTA- $\mathrm{Na}_{2}, 1.5 \mathrm{mM} \mathrm{MgCl} 2,0.5 \mathrm{mM}$ GSSG, $50 \mu \mathrm{M} \mathrm{NADPH}$, and enzyme extract containing $100 \mu \mathrm{g}$ protein in a total volume of $1 \mathrm{~mL}$. One unit of GR activity was defined as the quantity of GR required to cause a $1 \mathrm{mM}$ decrease in the NADPH concentration per minute.

\subsection{Statistics}

Values cited in this paper were obtained from fully independent samples, even for nondestructive measurements (e.g., $\mathrm{Fv} / \mathrm{Fm}$ measurements were not repeated on the same tissue during a time course). Differences were considered to be significant at a probability of $5 \%(P<0.05)$. Tests were performed using the SPSS 13.0 statistical program.

\section{Results}

\subsection{Seedling Growth and Fv/Fm}

Shoot growth as expressed by shoot and root lengths varied depending on the $\mathrm{Cd}^{2+}$ concentration in the nutrient bath. Compared with the control groups, no significant difference was detected in shoot and root lengths after 4-day exposure to the 10 and $100 \mu \mathrm{M} \mathrm{Cd}^{2+}$ concentrations $(P>0.05)$ in HY19, HY22, HY23 and LH11, with an exception to the root growth in FH3 $(P<0.05$, Figure 1$)$. High concentrations of $\mathrm{Cd}^{2+}(500 \mu \mathrm{M})$ significantly retarded the growth of the seedlings in all five of the cultivars $(P<0.05)$ and resulted in the browning and malformation of the root tips in all five peanut cultivars. The browning of roots was not observed at 10 and 100 $\mu \mathrm{M} \mathrm{Cd}^{2+}$ in the 4-day test.

At $10 \mu \mathrm{M} \mathrm{Cd}^{2+}, \mathrm{Fv} / \mathrm{Fm}$ did not differ significantly from the control groups in all five of the cultivars $(P>0.05$, Figure 2). When exposed to $100 \mu \mathrm{M} \mathrm{Cd}^{2+}$, the significant decline in $\mathrm{Fv} / \mathrm{Fm}$ was only detected in $\mathrm{FH} 3(P<0.05)$. However, a high concentration of $\mathrm{Cd}^{2+}(500 \mu \mathrm{M})$ significantly decreased the value of $\mathrm{Fv} / \mathrm{Fm}$ in all five of the cultivars $(P<0.05)$.

\subsection{ROS Production and Lipid Peroxidation}

The exposure of peanut seedlings to $\mathrm{Cd}^{2+}$ resulted in the oxidation of DCFH to DCF in comparison to the control group, which indicates the production of ROS under $\mathrm{Cd}^{2+}$ stress in all five of the cultivars (Figure 3). After a 
96-h exposure to $10 \mu \mathrm{M} \mathrm{Cd}^{2+}, \mathrm{H}_{2} \mathrm{O}_{2}$ content did not markedly increase in all of the cultivars $(P>0.05)$. When seedlings were exposed to 100 and $500 \mu \mathrm{M} \mathrm{Cd}{ }^{2+}$, the increase in $\mathrm{H}_{2} \mathrm{O}_{2}$ content correlated to the $\mathrm{Cd}^{2+}$ concentration $(P<0.05)$, indicating that the higher concentrations of $\mathrm{Cd}^{2+}$ increased the production of ROS.

Malondialdehyde (MDA) content was measured to evaluate the level of lipid peroxidation. Ten $\mu \mathrm{M}$ of $\mathrm{Cd}^{2+}$ resulted in a slightly increased content of MDA in the crude extracts of both shoots and roots in comparison with the control groups, but there were no statistically significant differences $(P>0.05$, Figure 4$)$. Exposure to 100 and $500 \mu \mathrm{M} \mathrm{Cd}^{2+}$ increased the MDA content in both shoots and roots of all five of the peanut cultivars $(P<$ $0.05)$.

\subsection{Activities of Antioxidant Enzymes}

In shoots, $10 \mu \mathrm{M} \mathrm{Cd}^{2+}$ significantly increased the activity of POD $(P<0.05)$ in all five cultivars, but the activity of SOD, CAT and GR remained unchanged when compared with the related control groups $(P>0.05$, Figure 5, A1-A4). The exposure to $100 \mu \mathrm{M} \mathrm{Cd}^{2+}$ markedly enhanced the activities of four enzymes studied. At $500 \mu \mathrm{M}$ $\mathrm{Cd}^{2+}$, the activity of SOD, CAT and GR were significantly increased $(P<0.05)$, and the activity of POD was unchanged $(P>0.05)$ in all five cultivars when compared to the control groups.

There were no significant differences detected in SOD and GR activity after the 4-day treatment of $10 \mu \mathrm{M} \mathrm{Cd}^{2+}$ in the roots of all five cultivars $\left(P>0.05\right.$, Figure 5, B1-B4). But this $\mathrm{Cd}^{2+}$ level caused a significant increase in the activity of CAT and POD $(P<0.05)$. In the presence of $100 \mu \mathrm{M} \mathrm{Cd}^{2+}$, the activity of the antioxidant enzymes studied were increased in the roots $(P<0.05)$. However, the treatment with $500 \mu \mathrm{M} \mathrm{Cd}^{2+}$ did not change the activity of SOD and CAT $(P>0.05)$ but did decrease the activity of POD and GR $(P<0.05)$.

\section{Discussion}

\subsection{Disturbances in the Growth and Photosynthetic Rate}

High $\mathrm{Cd}^{2+}$ concentrations $(500 \mu \mathrm{M})$ resulted in a reduction in seedlings growth, expressed as shoot and root length, induced root browning and inhibited PS II activity in all five of the cultivars. No visual symptoms from $\mathrm{Cd}^{2+}$ toxicity were detected at 10 and $100 \mu \mathrm{M} \mathrm{Cd}^{2+}$. However, cultivar $\mathrm{FH} 3$ was sensitive to $100 \mu \mathrm{M} \mathrm{Cd}^{2+}$ for root growth and in $\mathrm{Fv} / \mathrm{Fm}$ values. The inhibition of growth induced by $\mathrm{Cd}^{2+}$ was mainly due to the effect on photosynthesis rate (Sandalio et al. 2001). The inhibition of biomass production and the rate of photosynthesis from $\mathrm{Cd}^{2+}$ stress has been previously reported in other plants species (Lin et al. 2007; Hayat et al. 2007; Xu et al. 2008). Shi and Cai (2008) reported that $\mathrm{Cd}^{2+}$ treatment $(10,50,100 \mu \mathrm{M})$ caused an inhibition in the net photosynthetic rate of 14-d-old peanut seedlings. In our study, there was no significant difference in $\mathrm{Fv} / \mathrm{Fm}$ values found at 10 and $100 \mu \mathrm{M} \mathrm{Cd}^{2+}$ in all five cultivars, which may be attributed to the relationship between the growth stage and the sensitivity toward $\mathrm{Cd}^{2+}$ stress.

It has been previously reported that low levels of $\mathrm{Cd}^{2+}$ can have a positive effect on plant growth (Sanità di Toppi and Gabbrielli 1999; Lin et al. 2007). However, the stimulatory effect of $\mathrm{Cd}^{2+}$ on the growth of the peanut seedlings was not observed in the dose range tested in this study. In addition, the inhibition of seed germination was not observed in all five of the peanut cultivars, even in the presence of high concentrations of $\mathrm{Cd}^{2+}(500 \mu \mathrm{M})$. This result was similar to the results observed in wheat, barley and rice (Titov et al. 1995; Rascio et al. 2008).

\subsection{ROS Accumulation and Lipid Peroxidation}

The increase in the fluorescence of DCF indicated that there was a production of ROS resulting from $\mathrm{Cd}^{2+}$ stress. $\mathrm{H}_{2} \mathrm{O}_{2}$, a form of ROS, is uncharged and readily diffuses across biological membranes into the nutrient solution (Lesser 2006) and reacts with DCFH to produce DCF, which can be easily detected (Gomes et al. 2005). A comparison of $\mathrm{H}_{2} \mathrm{O}_{2}$ content among the five cultivars showed that 100 and $500 \mu \mathrm{M} \mathrm{Cd}^{2+}$ resulted in a sustained increase in fluorescence, indicating the accumulation of ROS induced by Cd stress. The accumulation of ROS further increased the level of lipid peroxidation in both shoots and roots of peanut cultivars.

It is known that the balance of the steady-state levels of ROS is determined by the interplay between different ROS-producing and ROS-scavenging agents (Seregin and Ivanov 2001; Benavides et al. 2005). Some studies showed that the homeostasis of ROS is interrupted by $\mathrm{Cd}^{2+}$ stress in plants (Sanità di Toppi and Gabbrielli 1999; Benavides et al. 2005). The continued presence of ROS would have detrimental effects on the peanut seedlings if they could not be rapidly removed (Lesser 2006; Clemens 2006). In this study, 100 and $500 \mu \mathrm{M} \mathrm{Cd}^{2+}$ increased the production of ROS; the latter was parallel to the degree of lipid peroxidation and related to the changes in growth and photosynthesis rates. Similar trends have been reported in other species (Lagriffoul et al. 1998; Sandalio et al. 2001; Schützendübel et al. 2002; Lin et al. 2007). 


\subsection{Changes in ROS-related Enzymes}

To defend against oxidative stress and scavenge ROS, plants possess a well-organized antioxidant defense system that contains antioxidative enzymes and antioxidants (Apel and Hirt 2004; Hall 2002). The cooperative function of these antioxidative enzymes and low molecular weight antioxidants play an important role in the scavenging of ROS and maintaining the physiological redox state of the organism (Lesser 2006).

At $10 \mu \mathrm{M} \mathrm{Cd}^{2+}$, activity of POD in shoots and activity of CAT and POD in roots increased to cope with $\mathrm{Cd}^{2+}$ stress, but this concentration of $\mathrm{Cd}^{2+}$ did not result in an accumulation of ROS. It is likely that oxidative stress was inhibited by the function of defensive system in this stage of the peanut seedling. However, $100 \mu \mathrm{M} \mathrm{Cd}^{2+}$ caused oxidative stress and increased the activity of enzymes studied in both shoots and roots. The increased activity of SOD, CAT, POD and GR caused by $\mathrm{Cd}^{2+}$ has been previously observed in several plant species and is considered to be an adjustment response to stress (Lagriffoul et al. 1998; Dinakar et al. 2008; Xu et al. 2008).

At the highest concentration of $\mathrm{Cd}^{2+}(500 \mu \mathrm{M})$ tested, the activity of all four antioxidative enzymes tested were inhibited in roots, whereas in shoots, only POD was inhibited. As previously reported in other plants, high concentrations of $\mathrm{Cd}^{2+}$ resulted in serious phytotoxicity (Lagriffoul et al. 1998). $\mathrm{Cd}^{2+}$ accumulation in plants and Cd-induced inhibition of orderly physiological functions were also associated with $\mathrm{H}_{2} \mathrm{O}_{2}$ accumulation and growth retardation in plant development (Benavides et al. 2005). The exposure to high $\mathrm{Cd}^{2+}$ concentrations might directly cause the inhibition of the antioxidative enzymes by $\mathrm{Cd}^{2+}$ binding (Chen et al. 2003; Clemens 2006; Hayat et al. 2007).

Cadmium stress induced more damage to roots than to shoots in the five peanut cultivars studied. This conclusion is based on the concentrations of $\mathrm{H}_{2} \mathrm{O}_{2}$ and $\mathrm{MDA}$, on the varying patterns of the activity of the antioxidative enzymes in different $\mathrm{Cd}^{2+}$ concentrations. Roots were directly exposed to $\mathrm{Cd}^{2+}$ in the medium, while shoots were not directly exposed and might be less impaired by oxidative stress.

The differences in responses to $\mathrm{Cd}$ are surprisingly small among the five cultivars. The result might indicate that the five cultivars in this study were all Cd-sensitive genotypes (Metwally et al. 2005). However, we found FH3 was more sensitive to $\mathrm{Cd}^{2+}$ stress than the other four cultivars. Further investigation is needed to illuminate whether this sensitivity is due to the genotypic and ecotypic differences of the peanut cultivars.

\section{References}

Adams, W. W. III, \& Demmig-Adams, B. (2004). Chlorophyll fluorescence as a tool to monitor plant response to the environment. In: Papageorgiou G C, Govindjee (Ed.), Advances in photosynthesis and respiration. Chlorophyll Fluorescence: A Signature of Photosynthesis. The Netherlands, Springer, 583-604.

Aina, R, Labra, M, Fumagalli, P, et al. (2007). Thiol-peptide level and proteomic changes in response to cadmium toxicity in Oryza sativa L. roots. Environmental and Experimental Botany, 59, 381-392. http://dx.doi.org/10.1016/j.envexpbot.2006.04.010

Apel, K., Hirt, H. (2004). Reactive oxygen species: metabolism, oxidative stress, and signal transduction. Annual Review of Plant Biology, 55, 373-399. http://dx.doi.org/10.1146/annurev.arplant.55.031903.141701

Arduini, I., Masoni, A., Mariotti, M., et al. (2004). Low cadmium application increase miscanthus growth and cadmium translocation. Environmental and Experimental Botany, 52, 153-164. http://dx.doi.org/10.1016/j.envexpbot.2004.01.001

Benavides, M. P., Gallego, S. M., Tomaro, M. L. (2005). Cadmium toxicity in plants. Brazilian Journal of Plant Physiology, 17, 21-34. http://dx.doi.org/10.1590/S1677-04202005000100003

Beutler E. (1975). Catalase. In: Beutler, E. (Ed.), Red Cell Metabolism. Grune and Stratton, New York, 105.

Bradford, E. (1976). A rapid and sensitive method for the quantification of microgram quantities of protein utilizing the priciple of protein-dye binding. Analytical Biochemistry, 72, 248-254. http://dx.doi.org/10.1016/0003-2697(76)90527-3

Buege, J., Aust, S. D. (1978). Microsomal lipid peroxidation. Methods in Enzymology, 52, 302-306. http://dx.doi.org/10.1016/S0076-6879(78)52032-6

Chen, Y. X., He, Y. F., Luo, Y. M., et al. (2003). Physiological mechanism of plant roots exposed to cadmium. Chemosphere, 50, 789-793. http://dx.doi.org/10.1016/S0045-6535(02)00220-5

Clemens, S. (2001). Molecular mechanisms of plant metal tolerance and homeostasis. Planta, 212, 475-486. http://dx.doi.org/10.1007/s004250000458

Clemens, S. (2006). Toxic metal accumulation, responses to exposure and mechanisms of tolerance in plants. 
Biochimie, 88, 1707-1719. http://dx.doi.org/10.1016/j.biochi.2006.07.003

Clemens, S., Palmgren, M. G., \& Krämer, U. (2002). A long way ahead: understanding and engineering plant metal accumulation. Trends in Plant Science, 7, 309-315. http://dx.doi.org/10.1016/S1360-1385(02)02295-1

Dinakar, N., Nagajyothi, P. C., Suresh, S., et al. (2008). Phytotoxicity of cadmium on protein, proline and antioxidant enzyme activities in growing Arachis hypogaea L. seedlings. Journal of Environmental Sciences, 20 , 199-206. http://dx.doi.org/10.1016/S1001-0742(08)60032-7

Ding, B. Z., Shi, G. X., Xu, Y., et al. (2007). Physiological responses of Alternanthera philoxeroides (Mart.) Griseb leaves to cadmium stress. Environmental Pollution, 147, 800-803. http://dx.doi.org/10.1016/j.envpol.2006.10.016

Ekmekci, Y., \& Terzioglu, S. (2005). Effects of oxidative stress induced by paraquat on wild and cultivated wheats. Pesticide Biochemistry and Physiology, 83, 69-81. http://dx.doi.org/10.1016/j.pestbp.2005.03.012

Gomes, A., Fernandes, E., \& Lima, J. L. F. C. (2005). Fluorescence probes used for detection of reactive oxygen species. Journal of Biochemical and Biophysical Methods, 65, 45-80. http://dx.doi.org/10.1016/j.jbbm.2005.10.003

Guo, T., Zhang, G., Zhou, M., et al. (2004). Effects of aluminum and cadmium toxicity on growth and antioxidant enzyme activities of two barley genotypes with different Al resistance. Plant and Soil, 258, 241-248. http://dx.doi.org/10.1023/B:PLSO.0000016554.87519.d6

Hall, J. L. (2002). Cellular mechanisms for heavy metal detoxification and tolerance. Journal of Experimental Botany, 53, 1-11. http://dx.doi.org/10.1093/jexbot/53.366.1

Hayat, S., Ali, B., Aiman Hasan, S., et al. (2007). Brassinosteroid enhanced the level of antioxidants under cadmium stress in Brassica juncea. Environmental and Experimental Botany, 60, 33-41. http://dx.doi.org/10.1016/j.envexpbot.2006.06.002

Järup, L. (2002). Cadmium overload and toxicity. Nephrology Dialysis Transplantation, 17, 35-39. http://dx.doi.org/10.1093/ndt/17.suppl_2.35

Lagriffoul, A., Mocquot, B., Mench, M., et al. (1998). Cadmium toxicity effects on growth, mineral and chlorophyll contents, and activities of stress related enzymes in young maize plants (Zea mays L.). Plant and Soil, 200, 241-250. http://dx.doi.org/10.1023/A:1004346905592

Lesser, M. P. (2006). Oxidative stress in marine environments: Biochemistry and Physiological Ecology. Annual Review of Physiology, 68, 253-278. http://dx.doi.org/10.1146/annurev.physiol.68.040104.110001

León, A. M., Palma, J. M., Corpas, F. J., et al. (2002). Antioxidative enzymes in cultivars of pepper plants with different sensitivity to cadmium. Plant Physiology and Biochemistry, 40, 813-820.

Lin, R. Z., Wang, X. R., Luo, Y., et al. (2007). Effects of soil cadmium on growth, oxidative stress and antioxidant system in wheat seedlings (Triticum aestivum L.). Chemosphere, 69, 89-98. http://dx.doi.org/10.1016/j.chemosphere.2007.04.041

Liu, H. J., Zhang, J. L., Christie, P., et al. (2008). Influence of iron plaque on uptake and accumulation of Cd by rice (Oryza sativa L.) seedlings grown in soil. Science of the Total Environment, 394, 361-368. http://dx.doi.org/10.1016/j.scitotenv.2008.02.004

Metwally, A., Safronova, V. I., Belimov, A. A., et al. (2005). Genotypic variation of the response to cadmium toxicity in Pisum sativum L. Journal of Experimental Botany, 56, 167-178.

Mishra, N. P., Mishra, R. K., \& Singhal, G. S. (1993). Changes in the activities of antioxidant enzymes during exposure of intact wheat leaves to strong visible light at different temperatures in the presence of protein synthesis inhibitors. Plant Physiology, 102, 903-908.

Rascio, N., Vecchia, F. D., Rocca, N. L., et al. (2008). Metal accumulation and damage in rice (cv. Vialone nano) seedlings exposed to cadmium. Environmental and Experimental Botany, 62, 267-278. http://dx.doi.org/10.1016/j.envexpbot.2007.09.002

Razinger, J., Dermastia, M., Koce, J. D., et al. (2008). Oxidative stress in duckweed (Lemna minor L.) caused by short-term cadmium exposure. Environmental Pollution, 153, 687-694. http://dx.doi.org/10.1016/j.envpol.2007.08.018

Sandalio, L. M., Dalurzo, H. C., Gómez, M., et al. (2001). Cadmium-induced changes in the growth and oxidative metabolism of pea plants. Journal of Experimental Botany, 52, 2115-2126. 
Sanità di Toppi, L., \& Gabbrielli, R. (1999). Response to cadmium in higher plants. Environmental and Experimental Botany, 41, 105-130. http://dx.doi.org/10.1016/S0098-8472(98)00058-6

Sanità di Toppi, L., Pawlik-Skowrońska, B., Vurro, E., et al. (2008). First and second line mechanisms of cadmium detoxification in the lichen photobiont Trebouxia impressa (Chlorophyta). Environmental Pollution, 151, 280-286. http://dx.doi.org/10.1016/j.envpol.2007.06.010

Schützendübel, A., Nikolova, P., Rudolf, C., et al. (2002). Cadmium and $\mathrm{H}_{2} \mathrm{O}_{2}$-induced oxidative stress in Populus $\times$ canescens roots. Plant Physiology and Biochemistry, 40, 577-584.

Seregin, I. V., \& Ivanov, V. B. (2001). Physiological Aspects of Cadmium and Lead Toxic Effects on Higher Plants. Russian Journal of Plant Physiology, 48, 523-544. http://dx.doi.org/10.1023/A:1016719901147

Shi, G. R., \& Cai, Q. S. (2008). Photosynthetic and anatomic responses of peanut leaves to cadmium stress. Photosynthetica, 46, 627-630. http://dx.doi.org/10.1007/s11099-008-0107-8

Sobkowiak, R., \& Deckert, J. (2006). Proteins induced by cadmium in soybean cells. Journal of Plant Physiology, 163, 1203-1206. http://dx.doi.org/10.1016/j.jplph.2005.08.017

Titov, A. F., Talanova, V. V., \& Boeva, N. P. (1995). Growth responses of barley and wheat seedlings to lead and cadmium. Biologia Plantarum, 38, 431-436. http://dx.doi.org/10.1007/BF02896675

Uraguchi, S., Watanabe, I., Yoshitomi, A., et al (2006). Characteristics of cadmium accumulation and tolerance in novel Cd-accumulating crops, Avena strigosa and Crotalaria juncea. Journal of Experimental Botany, 57, 2955-2965. http://dx.doi.org/10.1093/jxb/erl056

Xu, P., Zou, J., Meng, Q. M., et al. (2008). Effects of $\mathrm{Cd}^{2+}$ on seedling growth of garlic (Allium sativum L.) and selected physiological and biochemical characters. Bioresource Technology, 99, 6372-6378. http://dx.doi.org/10.1016/j.biortech.2007.11.073

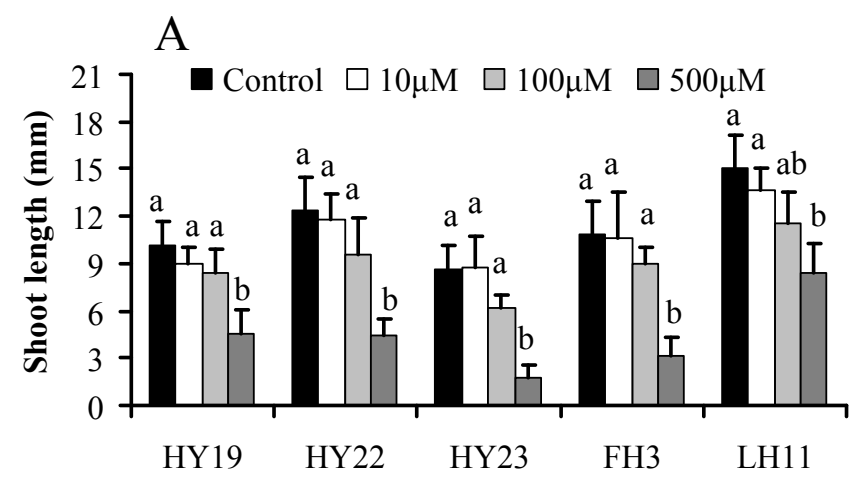

$\mathrm{B}$

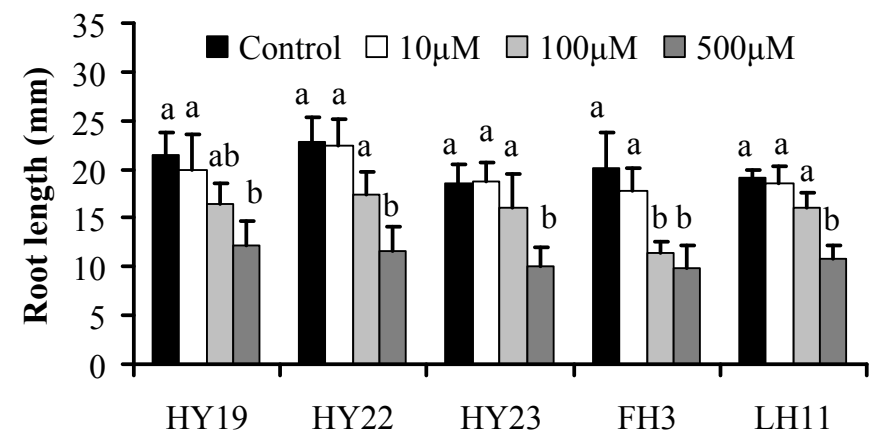

Figure 1. Shoot (A) and root (B) lengths of the five peanut (Arachis hypogaea L.) cultivars exposed to different $\mathrm{Cd}$ concentrations. Vertical bars are the standard deviations $(\mathrm{n}=6)$. Values were compared within different $\mathrm{Cd}$ concentrations in the same cultivar. Those that were significantly different $(P<0.05)$ are indicated by different letters 


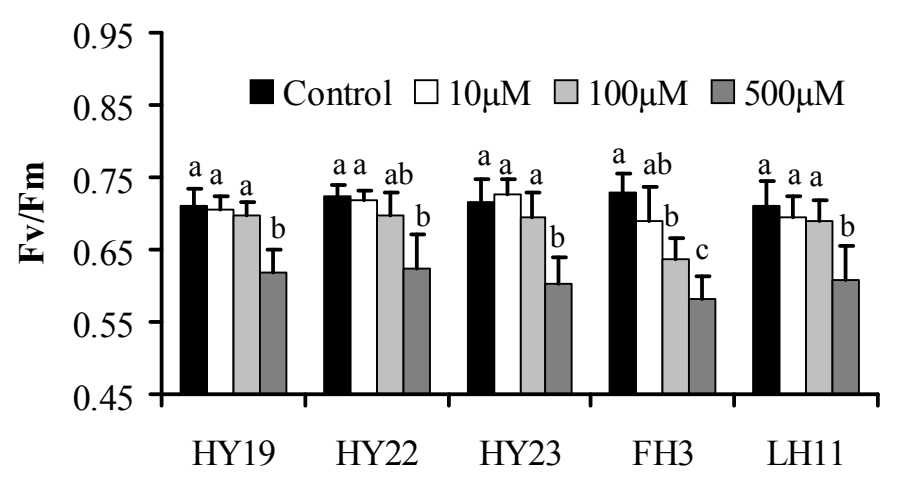

Figure 2. The maximal photochemical efficiency of PS II (Fv/Fm) of young seedlings from five peanut cultivars exposed to different $\mathrm{Cd}$ concentrations. Vertical bars are the standard deviations $(\mathrm{n}=6)$. Values were compared within different $\mathrm{Cd}$ concentrations in the same cultivar and significant differences $(P<0.05)$ are indicated by different letters

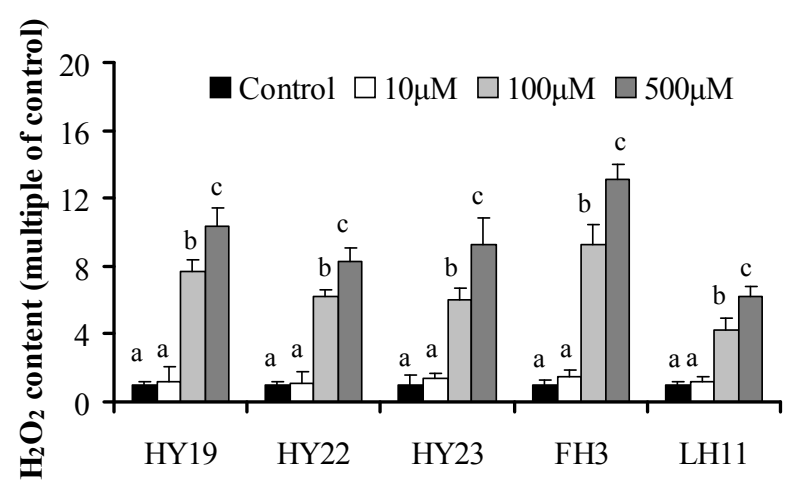

Figure 3. ROS content (A) measured as the increase in DCF fluorescence upon exposure to different Cd concentrations. ROS content was expressed as a multiple of the control. Vertical bars are standard deviations (n $=5$ ). Values were compared within different $\mathrm{Cd}$ concentrations in the same cultivar and significant differences $(P<0.05)$ are indicated by different letters 

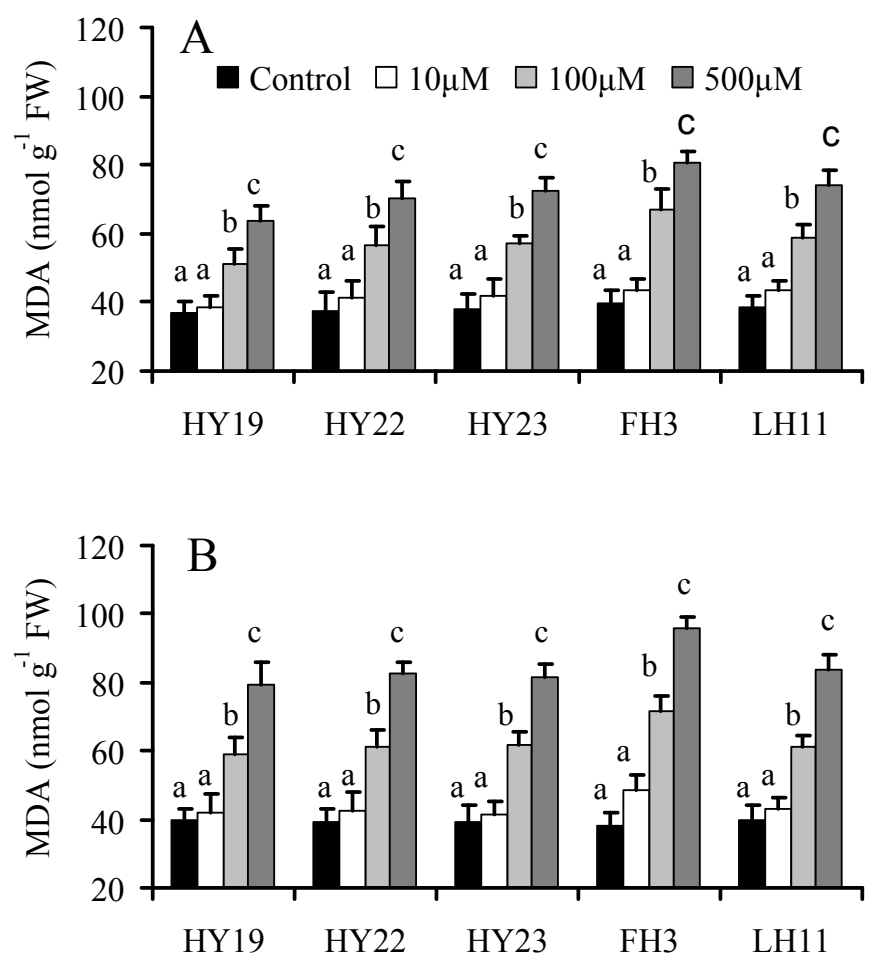

Figure 4. MDA content in shoots (A) and roots (B) of five different peanut cultivars after 4-day exposure to Cd. Vertical bars are standard deviations $(\mathrm{n}=4)$. Values were compared within different $\mathrm{Cd}$ concentrations in the same cultivar and significant differences $(P<0.05)$ are indicated by different letters 

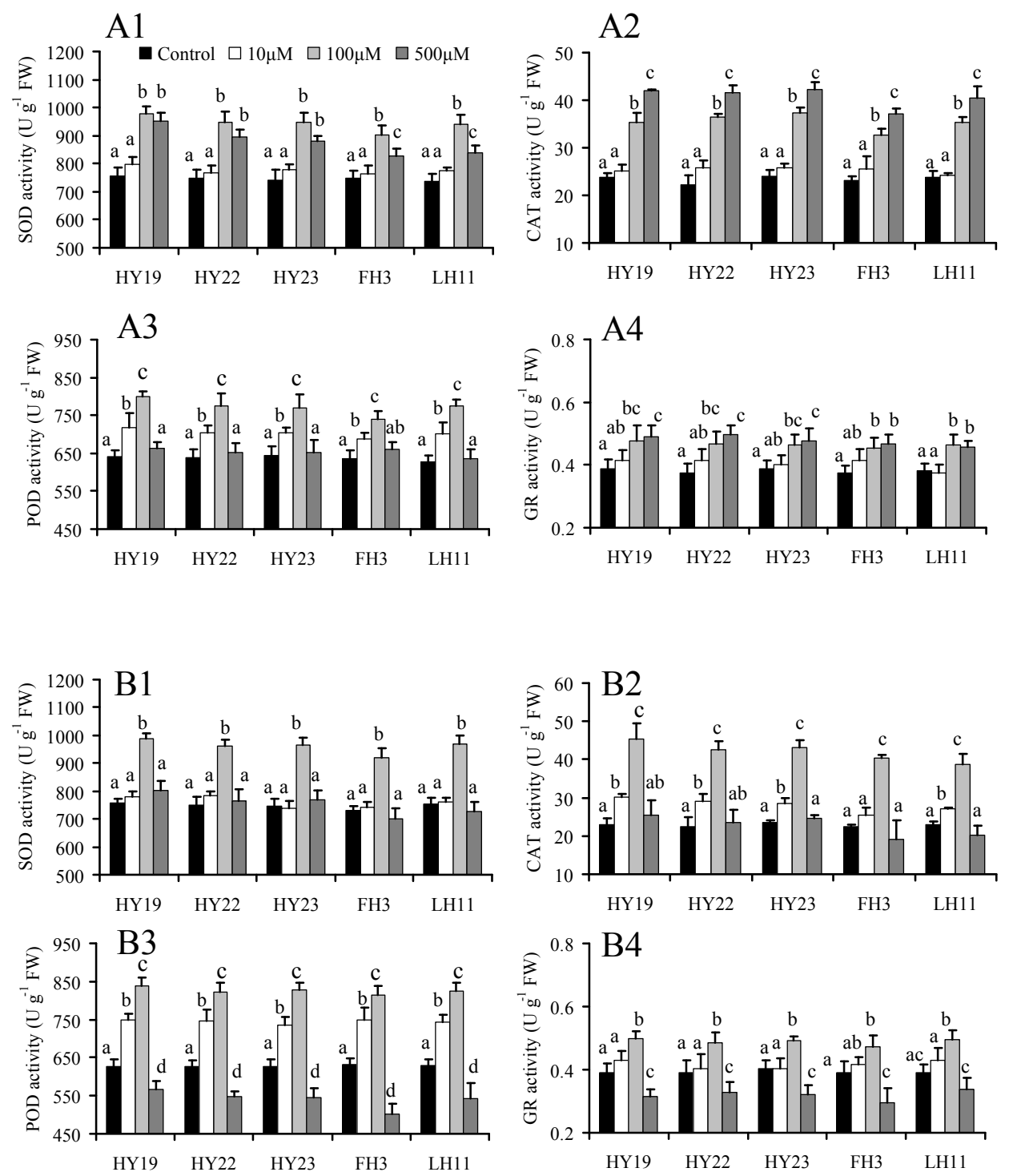

Figure 5. The activity of superoxide dismutase (SOD), catalase (CAT), peroxidase (POD) and glutathione reductase (GR) in the shoots (A1-A4) and the roots (B1-B4) exposed to different Cd concentrations. Vertical bars are standard deviations $(\mathrm{n}=4)$. Values were compared within different $\mathrm{Cd}$ concentrations in the same cultivar and significant differences $(P<0.05)$ are indicated by different letters 